\title{
3. Economic impact of skilled labor mobility within the ASEAN Economic Community
}

\section{Erwin Corong and Angel Aguiar}

\section{INTRODUCTION}

The Association of Southeast Asian Nations (ASEAN) has been actively pursuing trade integration for over 25 years. In 1992, members signed the ASEAN Free Trade Agreement (AFTA) to increase intra-ASEAN trade and improve the region's competitiveness by eliminating intraASEAN tariff and non-tariff barriers by $2015 .{ }^{1}$ The ASEAN Economic Community (AEC) was launched in 2015 with the primary aim of creating a single market and production base that would allow the free flow of goods, investments, and skilled labor within the region (ADB 2015). Although skilled labor liberalization has lagged behind trade and investment liberalization, Sugiyarto and Agunias (2014) argue that freer flows of skilled labor within ASEAN may help address the labor shortfalls and skill shortages the region currently faces.

The main objective of this chapter is to understand and quantify the potential impact on ASEAN member economies of skilled labor mobility under the AEC Mutual Recognition Arrangements (MRAs) - which took effect in 2015. As far as we are aware, no prior study has analyzed how the MRAs might impact each ASEAN economy. We fill this gap and contribute to policy research by carrying out simulation-based analyses with the aid of an economy-wide or computable general equilibrium (CGE) model to help us keep track of the likely direct and indirect effects that tariff elimination and freer mobility of skilled workers would have in their source and host countries.

CGE models are data intensive. For this study we use the GMig2 (Global Migration) Data Base and modeling framework. Both the GMig2 data and model (Walmsley et al. 2007) extend the widely used Global Trade Analysis Project (GTAP) data and model - by explicitly accounting for bilateral migration and remittances flows. The GTAP framework (Hertel 
1997) has been the basis for most analysis of free trade agreements since the mid-1990s. The GTAP model relies on the GTAP Data Base, which provides an exhaustive set of accounts measuring the value of annual flows of goods and services for the world economy with regional and sectoral detail. These flows, based on official data, include bilateral trade, transport, and protection matrices that link individual country/regional economic datasets. The most recent GTAP Data Base (version 9.0) covers 140 regions (120 countries and 20 aggregated regions), 57 sectors, and 8 factors of production (Aguiar et al. 2016).

An economy-wide framework like GMig2 is the appropriate methodology to analyze how labor migration scenarios might affect the ASEAN region and each member because it accounts for micro- and macroeconomic linkages. In this study, we use GMig2 to answer two questions: (i) would intra-ASEAN skills mobility bring economic benefits to each member and the ASEAN region as a whole; and (ii) would complementary policies that reduce wage differentials between migrants and permanent residents bring further economic gains?

We find that AFTA tariff elimination - coupled with (i) a policy allowing the freer flow of skilled labor within ASEAN and (ii) improvements in the initial host country's migrant-to-permanent resident wage ratio (improved wage differentials) - would result in gross domestic product (GDP) gains for AEC economies. This is due to the increased supply of skilled labor and higher investments, exports, and consumption on the back of higher remittances sent home by migrant workers. As such, our quantitative findings support the view (for example, Sugiyarto and Agunias 2014) that freer flows of skilled labor coupled with complementary policies that reduce national-level barriers would benefit ASEAN members and the region as a whole.

This chapter is organized as follows. Section 2 describes the key features of the methodology used. Section 3 analyzes the underlying data by focusing on each AEC member's economic structure, intra-ASEAN trade, and intra-ASEAN skilled labor migration flows. Section 4 describes the policy experiments and analyzes the simulation results. Finally, Section 5 outlines the insights gleaned from the simulation results, policy implications, and our agenda for future work.

\section{METHODOLOGY}

Analyzing the potential impacts of skills mobility within the AEC requires a model capable of tracing the transmission channels through which bilateral labor movements may affect each AEC member economy and 
their trading partners. To do this, we employ the GMig2 model (Walmsley et al. 2009) - a multi-sector, multi-country general equilibrium model that extends the widely used GTAP modeling framework (Hertel 1997; Corong et al. 2017) by explicitly accounting for bilateral labor flows and their consequent impacts on wages and migrant remittances.

The GTAP model is a relatively standard multi-sector, multi-region CGE model. It assumes constant returns to scale, and consists of equations that define agents' behavior and optimizing decisions (such as cost minimization and profit and utility maximization), market clearing conditions, and identities that satisfy accounting constraints. Figure 3.1 presents

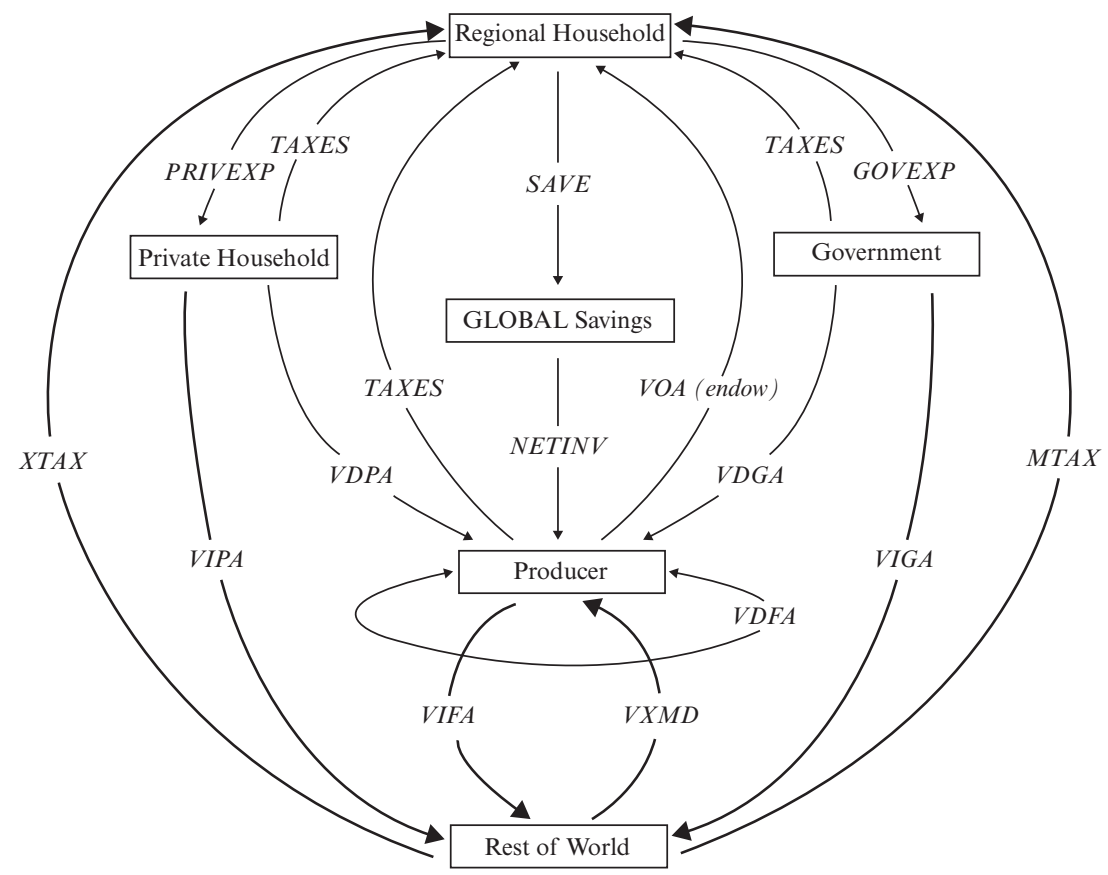

Note: $\quad$ GTAP $=$ Global Trade Analysis Project XTAX $=$ Export tax PRIVEXP $=$ Private Expenditure; GOVEXP = Government Expenditure; SAVE = Saving; VOA = Value of Output; Endow = Endowment; VIPA = Value Imported Expenditure by Private Households; VDPA = Value Domestic Expenditure by Private Households; VIGA = Value Imported Expenditure by Government; VDGA = Value Domestic Expenditure by Government; VIFA = Value Imported Expenditure by Firms; VDFA = Value Domestic Expenditure by Firms; MTAX - Import tax.

Source: Brockmeier (2001).

Figure 3.1 Schematic overview of the GTAP model 
a schematic representation of the GTAP modeling framework-similar to an economy's circular flow model. The figure suggests that GTAP not only allows us to trace the linkage within a country between each economic agent (firms, households, investment, and government), but also how these agents are linked to the rest of the world (see Hertel 1997; Brockmeier 2001; and Corong et al. 2017 for an updated schematic representation of the GTAP modeling framework and details on the latest version of the GTAP model).

The GMig2 model extends the core GTAP model by explicitly accounting for bilateral labor flows and their consequent impact on wages and migrant remittances. In this section, we explain just the key mechanisms affecting labor mobility; further technical details are found in Walmsley et al. (2009). The GMig2 model includes equations that track bilateral labor movements and their associated flow-on effects to each country's labor force $\left(\boldsymbol{L} \boldsymbol{F}_{i, r}\right)$ and population $\left(\boldsymbol{P O} \boldsymbol{P}_{c, r}\right)$ flows, as shown in Equations (3.1) and (3.2).

$$
\begin{aligned}
L F_{i, r} & =\Sigma_{c} L F_{i, c, r} \\
\boldsymbol{P O P}_{r} & =\Sigma_{c} \boldsymbol{P O P}_{c, r}
\end{aligned}
$$

These equations indicate that an increase in the number of migrant workers of skill $i$ from source region $c$ in host region $r$ would result in a reduction in the labor force and population in the source region $c$, and a consequent increase in the labor force and population in the host region $r .^{2}$

Note that the change in each region's population, as computed in Equation (3.2), may be more than the change in labor force. This occurs under the assumption that workers move with their families. In this chapter, we assume otherwise - that is, migrant workers do not move with their families due to the temporary nature of skills mobility within the AEC.

Moreover, there are two methods by which skills mobility within the AEC can be analyzed. The first is through three possible exogenous changes in labor supply: (i) change in the number of migrants from source region $c$ to host region $r$; (ii) change in total labor supply in host region $r$ to simulate a proportional increase in the stock of migrants coming from various source countries $c$ (as observed in the initial data); or (iii) change in the total supply of labor to simulate a proportional outflow of migrants to their home country.

The second method, which we use here, models skills mobility within the AEC via an endogenous mechanism that allows migrant workers to move from source country $c$ to host region $r$ based on real wage differences between their host $\left(\boldsymbol{R} \boldsymbol{W}_{i, c, r}\right)$ and source countries $\left(\boldsymbol{R} \boldsymbol{W}_{i, c, c}\right)$, as shown in Equation (3.3). 


$$
\boldsymbol{L F}_{i, c, r}=A_{i, c, r} \times\left[\frac{\boldsymbol{R} \boldsymbol{W}_{i, c, r}}{\boldsymbol{R} \boldsymbol{W}_{i, c, c}}\right]^{\sigma_{i, c, r}}
$$

The degree to which migrants respond to real wage differences is governed by the supply elasticity parameter represented by $\sigma_{i, c, r}$. Higher (lower) values assigned to the $\sigma_{i, c, r}$ parameter results in a greater (smaller) response of migrants to real wage differences. In the absence of econometric estimates, we set $\sigma_{i, c, r}$ for skilled labor to 1.0 - which means that migrants have a unitary elasticity response to real wage differences between their source and host countries. The exogenous coefficient $\left(\boldsymbol{A}_{i, c, r}\right)$, shown in Equation (3.3) accounts for other factors in the migration decision (such as language and other restrictions) and is calibrated from the underlying GMig2 Data Base explained below.

We use GMig2 version 9.0 data (2011 as base year), which categorizes the world economy into 57 sectors and 140 countries/regions. Like the model, the GMig2 data also extends the standard GTAP Data Base by explicitly accounting for bilateral labor flows and migrant and nonmigrant wages, along with bilateral remittances. These are constructed from various data sources such as: (i) the bilateral matrix of foreign-born populations from Ozden et al. (2010); (ii) labor force participation rates from the International Labour Organization (ILO); (iii) labor skill shares from Docquier et al. (2010); and (iv) data on GDP, population, and bilateral remittances from the World Bank.

Given our focus on skills mobility-and because this study is our maiden attempt to analyze skills mobility within the AEC - we aggregate the full GMig2 Data Base to 16 countries/regions, two labor types (classified into skilled and unskilled), ${ }^{3}$ and eight broad sectors (which include three service subsectors-business services, public and health services, and "other services"). These sectors include those occupations covered by AEC Mutual Recognition Arrangements (MRAs) - accountants, architects, dentists, engineers, medical practitioners, nurses, land surveyors, and tourism professionals. Table 3.1 shows that the aggregated GMig2 data distinguishes all AEC members except Myanmar, which in the original GTAP/GMig2 Data Base is aggregated with the "Rest of Southeast Asia" (including Myanmar and Timor-Leste). ${ }^{4}$

\section{BENCHMARK DATA}

Here we examine the underlying structure of our aggregated GMig2 Data Base. We pay particular attention to each AEC member's economic structure, intra-ASEAN trade, and intra-ASEAN skilled labor migration flows. 
Table 3.1 Regional and sectoral aggregation

\begin{tabular}{rllcll}
\hline No. & Country/Region & Code & No. & Sector & Code \\
\hline 1 & Australia/New Zealand & ANZ & 1 & Agriculture & AGR \\
2 & East Asia & XEA & 2 & $\begin{array}{l}\text { Forestry, fishing, and } \\
\text { mining }\end{array}$ & PRM \\
& & BRU & 3 & Processed food & PFD \\
3 & Brunei Darussalam & CAM & 4 & Textile and clothing & TEX \\
4 & Cambodia & INO & 5 & Other manufacturing & MNF \\
5 & Indonesia & LAO & 6 & Business services & OBS \\
6 & Lao People's Democratic & \\
& $\quad$ Republic (PDR) & & & & OSG \\
7 & Malaysia & MAL & 7 & Public and health services & SER \\
8 & Philippines & PHI & 8 & Other services & \\
9 & Singapore & SIN & & & \\
10 & Thailand & THA & & & \\
11 & Viet Nam & VIE & & & \\
12 & Rest of Southeast Asia & XSE & & & \\
& (including Myanmar) & & XSA & & \\
13 & South Asia & NAM & & \\
14 & North America & EU & & & \\
15 & European Union 27 & Rest of the World & ROW & & \\
\hline
\end{tabular}

Source: Authors' aggregation based on GTAP/GMig2 Data Base version 9 (see Appendix Tables 3A.1 and 3A.2 for detailed sectoral and regional concordance with the GTAP Data Base).

Table 3.2 shows both expenditure- and income-side GDP for 2011. Global GDP was \$71 trillion, with North America and Europe accounting for a combined 50\% share. Combined, Southeast Asian economies contributed $\$ 2$ trillion (roughly 3.1\%) of global GDP. Indonesia has the highest GDP among AEC members with $\$ 845$ billion, followed by Thailand and Singapore with $\$ 345$ billion and $\$ 274$ billion, respectively.

Figures 3.2 and Figure 3.3 decompose GDP into its components for each Southeast Asian economy. The expenditure-side GDP of Indonesia, the Lao PDR, the Philippines, and the Rest of Southeast Asia is mainly anchored on consumption, while the GDP of Brunei Darussalam and Singapore is mainly driven by exports (Figure 3.2). From the income side, Figure 3.3 shows that unskilled labor accounts for a significant share of GDP for most Southeast Asian economies - except for Singapore, where the share of skilled labor income roughly equals that of capital. Much of Brunei Darussalam's income-side GDP comes from capital and indirect taxes, with the latter mostly in the form of oil royalties. 


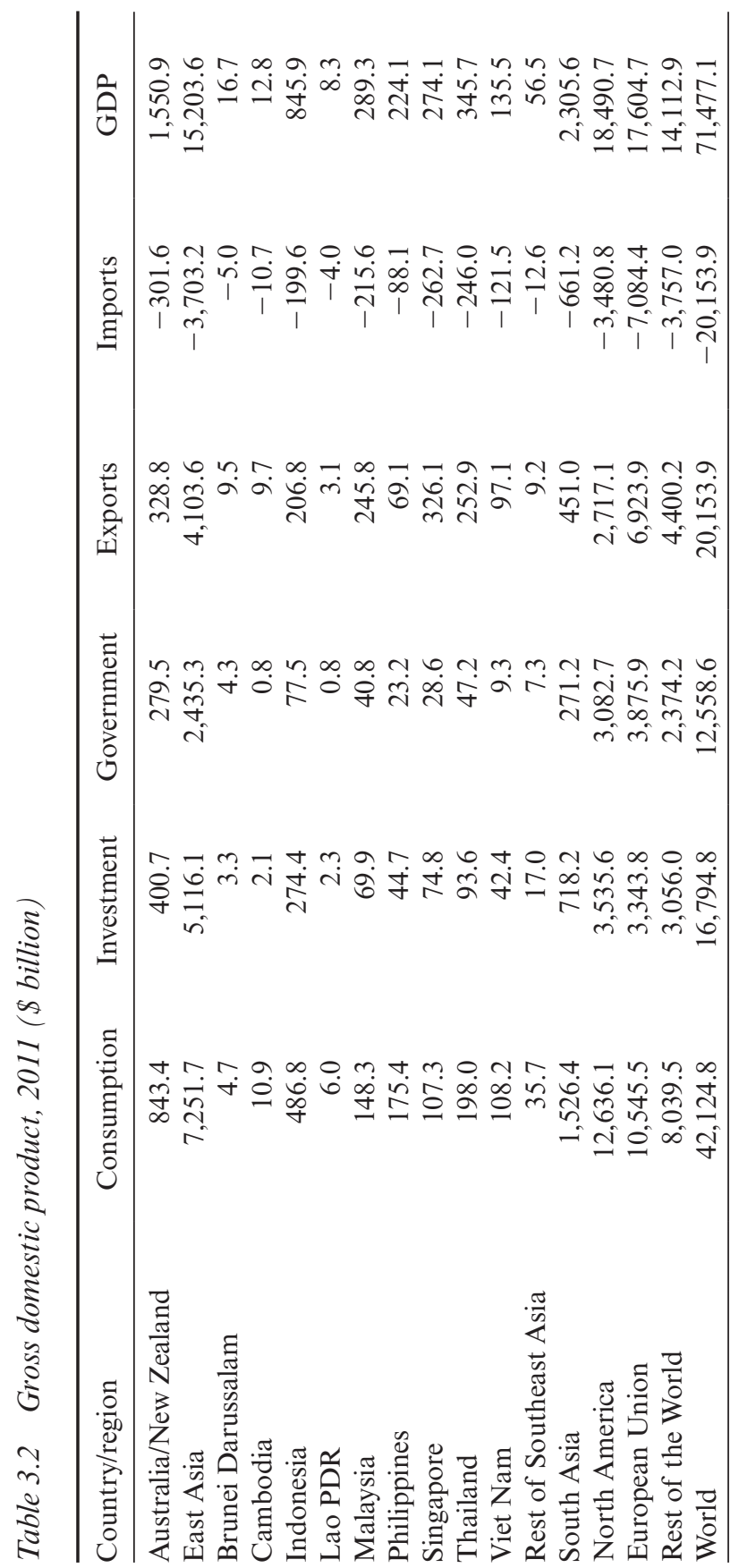

63 


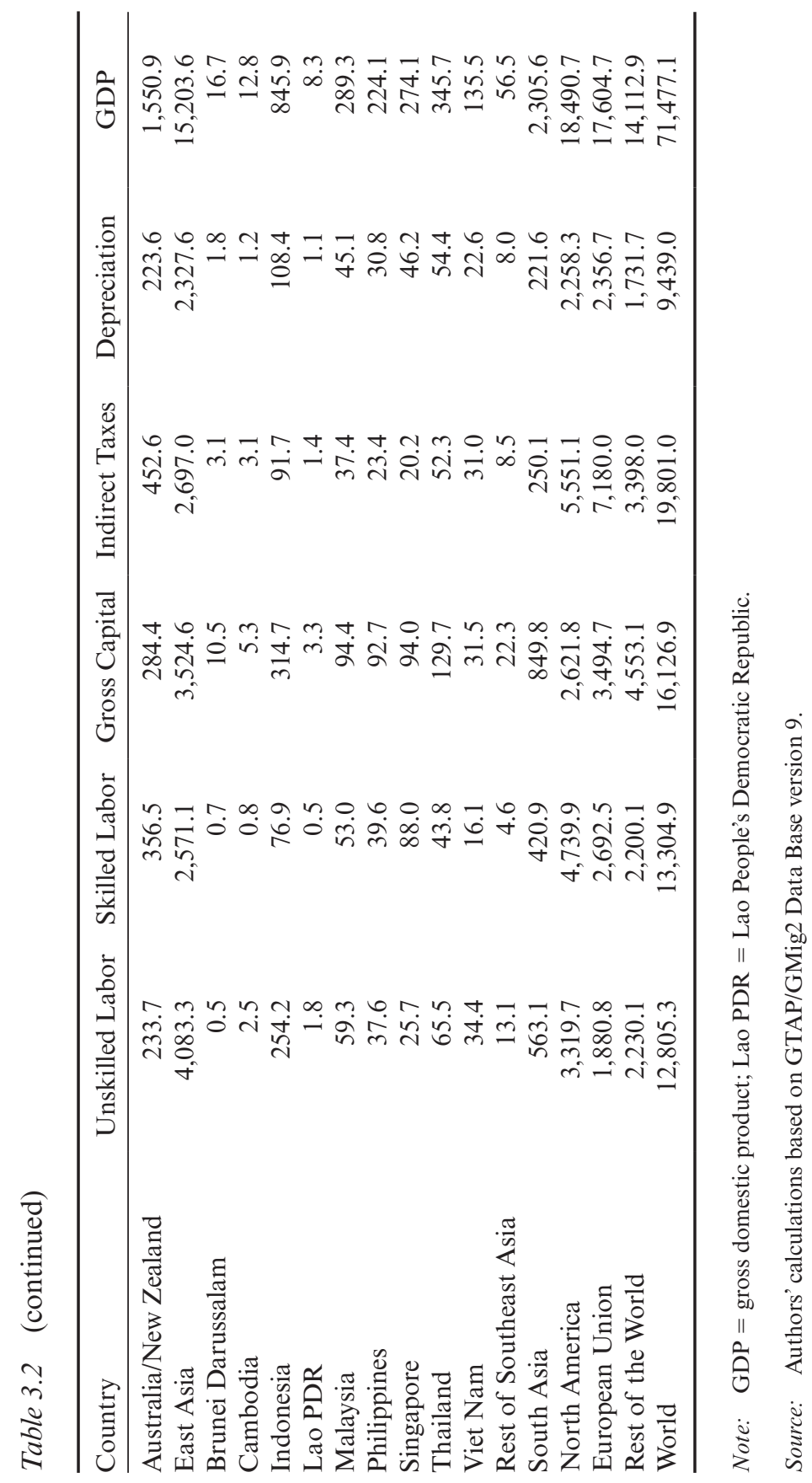




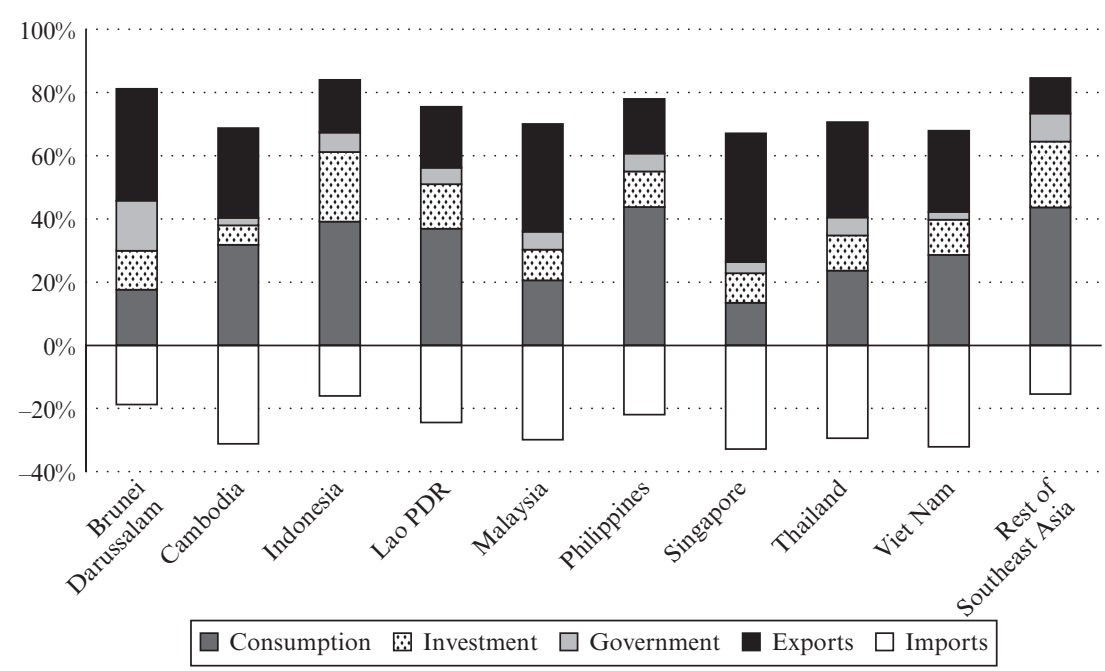

Note: $\quad$ Lao PDR $=$ Lao People's Democratic Republic.

Source: Authors' calculations based on GTAP/GMig2 Data Base version 9.

Figure 3.2 Expenditure-side gross domestic product, 2011 (\% share)

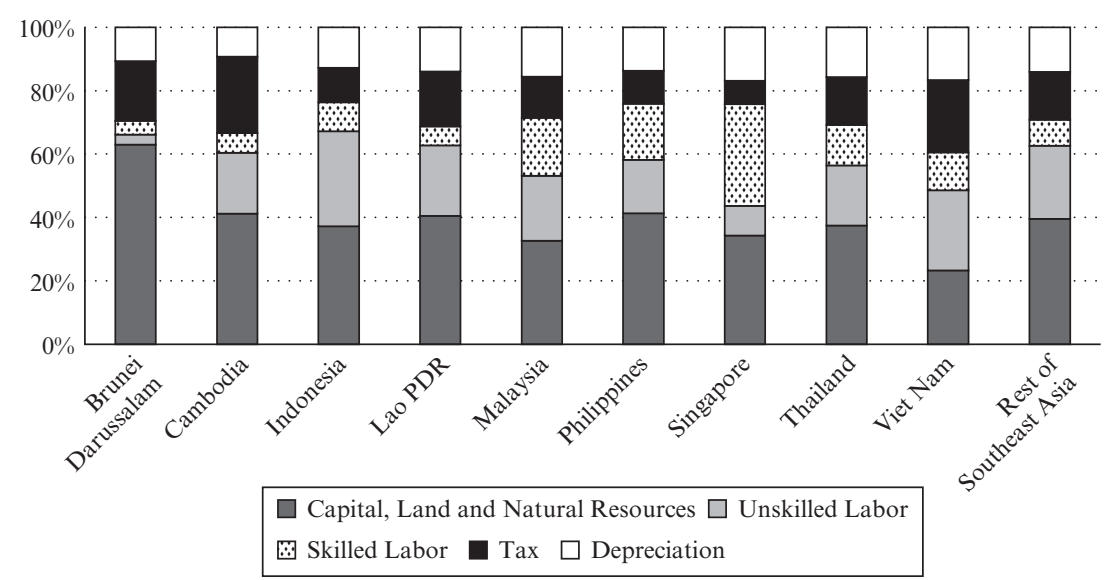

Note: $\quad$ Lao PDR $=$ Lao People's Democratic Republic.

Source: Authors' calculations based on GTAP/GMig2 Data Base version 9.

Figure 3.3 Income-side gross domestic product, 2011 (\% share) 


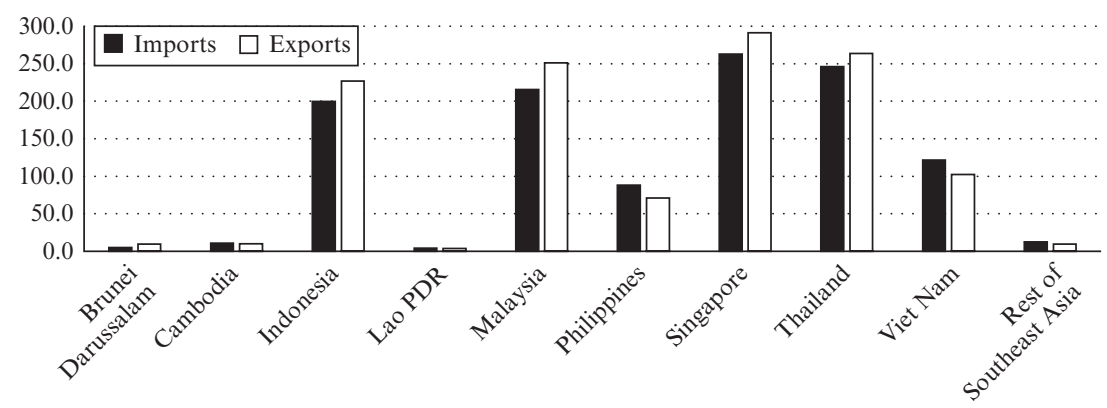

Note: $\quad$ Lao PDR $=$ Lao People's Democratic Republic.

Source: Authors' calculations based on GTAP/GMig2 Data Base version 9.

\section{Figure 3.4 Total exports and imports, 2011 (\$ billion)}

Figure 3.4 shows total exports and imports for each Southeast Asian country. Total trade (exports and imports) is highest in Singapore, followed by Thailand, Malaysia, and Indonesia. In 2011, these four countries - along with Brunei Darussalam - had trade surpluses, whereas Cambodia, the Lao PDR, the Philippines, Viet Nam, and the Rest of Southeast Asia recorded trade deficits.

Figure 3.5 shows the weighted average tariff rates faced and imposed by each Southeast Asian economy relative to all trading partners. The lighter bars show the average tariff rates faced by each country's exports, while the darker bars show the average tariff rates imposed on each country's imports. In general, both exports from and imports to Southeast Asia are

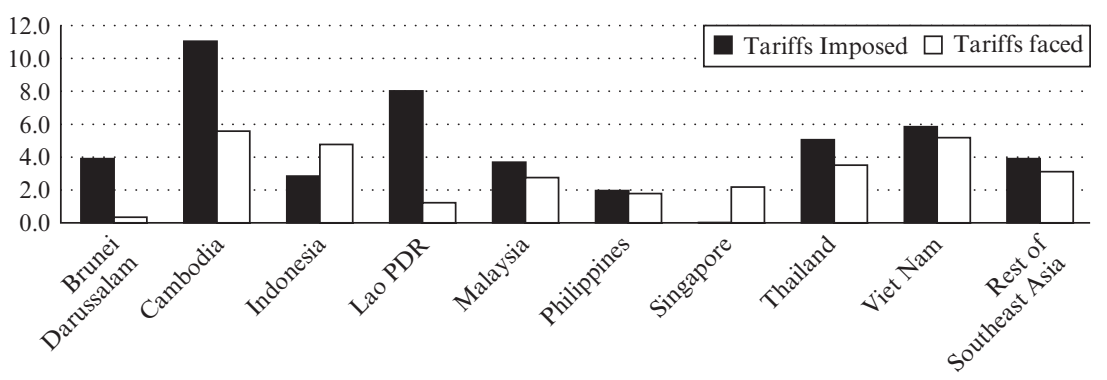

Note: $\quad$ Lao PDR $=$ Lao People's Democratic Republic.

Source: Authors' calculations based on GTAP/GMig2 Data Base version 9.

Figure 3.5 Tariffs faced and imposed, $2011(\%)$ 
levied average tariffs of less than $6 \%$. Exceptions are imports by Cambodia and the Lao PDR, which on average are levied at $11 \%$ and $8 \%$, respectively.

Table 3.3 presents bilateral trade flows for each Southeast Asian economy for 2011. Row headings show exporting countries, while column headings show importing countries - consequently, row entries show the value of exports, while column entries show the value of imports. For example, Singapore's exports to Malaysia in 2011 were valued at \$31.6 billion. Calculations from Table 3.3 suggest that Southeast Asian countries accounted for $5.8 \%$ of global imports and $6.1 \%$ of global exports, while intra-ASEAN trade accounted for just $1.2 \%$ of total global trade flows.

Figure 3.6 shows that Southeast Asian economies are highly specialized. Brunei Darussalam, the Lao PDR, and the Rest of Southeast Asia mainly export primary commodities such as oil and minerals, while Malaysia, the Philippines, Singapore, and Thailand mostly export manufactured goods. Textiles also account for a majority of Cambodia's exports, while exports of primary and manufactured goods account for a significant part of Indonesia's total exports. The contribution of services exports to total exports varies by country - ranging from 5\% in Indonesia to $24 \%$ in Singapore.

Figure 3.7 decomposes the share of each imported commodity to total imports for each Southeast Asian economy. The region mainly imports manufactured goods, with textiles accounting for $27 \%$ and $12 \%$ of total imports of Cambodia and Viet Nam, respectively. The share of services to total imports varies, ranging from $5 \%$ in the Lao PDR to $24 \%$ in Singapore.

Table 3.4 shows bilateral skilled labor flows (in thousands of people) within ASEAN. Row headings identify source countries, while column headings define host countries. For example, there are 74,500 skilled migrants from Malaysia working in Singapore. It also shows there are 172,000 intra-ASEAN skilled migrants, with roughly 54\% working in Singapore. Other major skilled migrant destinations are Thailand (14\% of total intra-ASEAN skilled labor migration flows), Malaysia (11\%), and Cambodia (10\%). The shaded cells indicate significant bilateral labor migration flows, which we will explore in Figure 3.8 below.

Table 3.5 shows the share of skilled migrants in the host country's labor force. On average, skilled migrants account for just $11.2 \%$ of ASEAN's total skilled labor force. Brunei Darussalam has the highest skilled migrant share of its labor force $(11.5 \%)$, followed by Singapore $(9.5 \%)$ and Cambodia (7.7\%), whereas the Rest of Southeast Asia (Myanmar and Timor-Leste) has a negligible skilled migrant share to its total labor force.

Figure 3.8 presents the composition of skilled migrants by host country, derived from the skilled migration flows shown in Table 3.4. Figure 3.8 


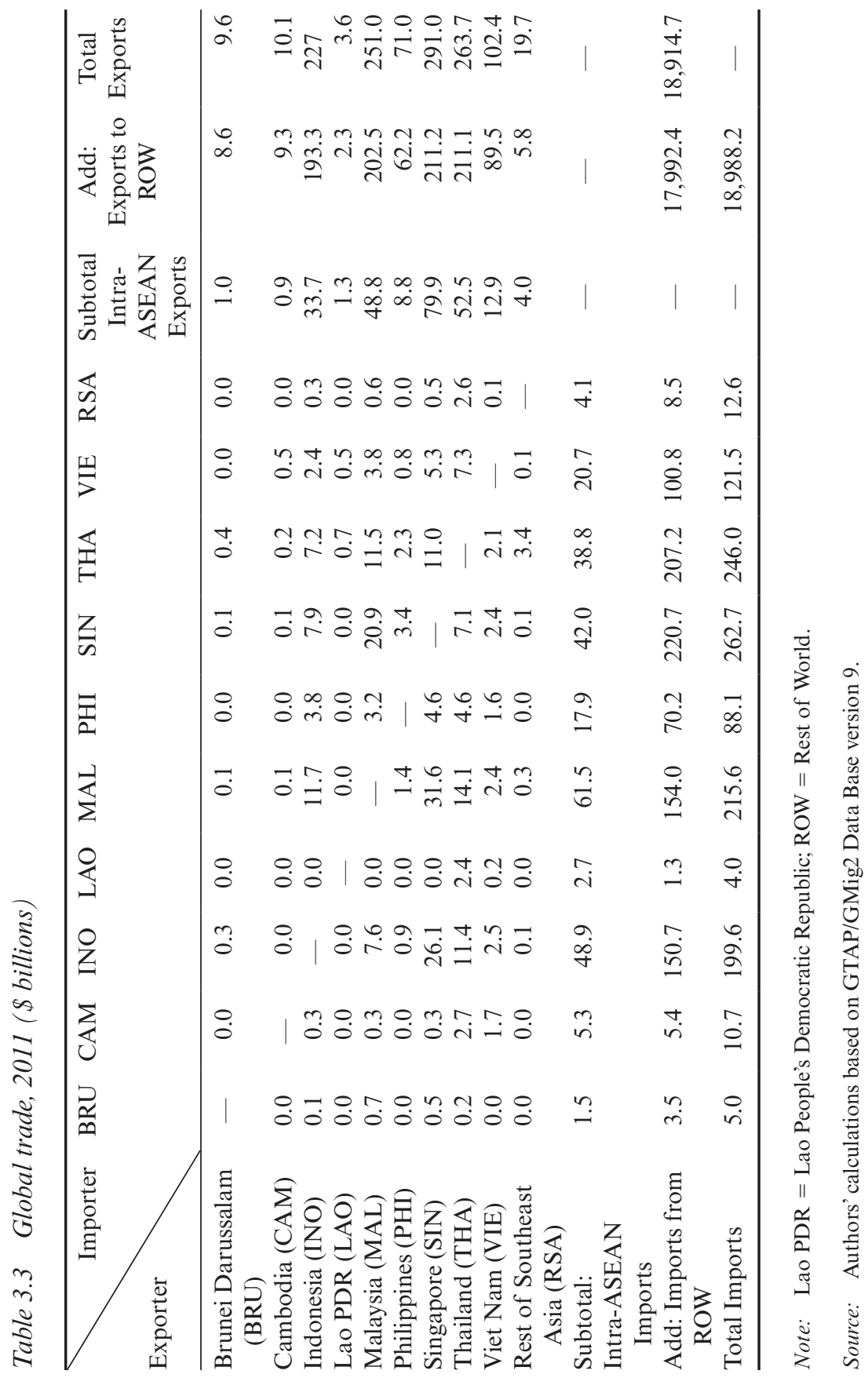




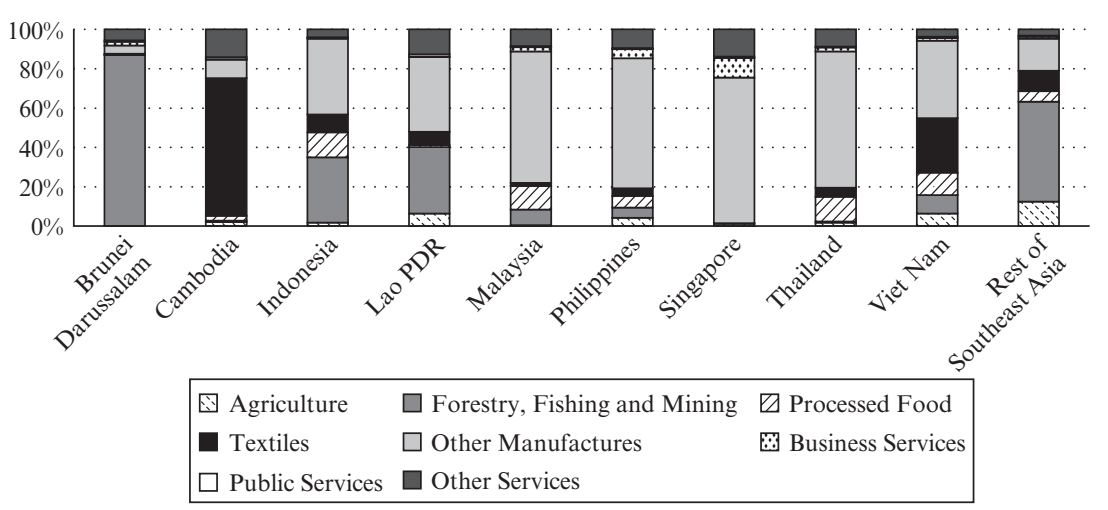

Note: $\quad$ Lao PDR $=$ Lao People's Democratic Republic.

Source: Authors' calculations based on GTAP/GMig2 Data Base version 9.

Figure 3.6 Exports by commodity, 2011 (\% share)

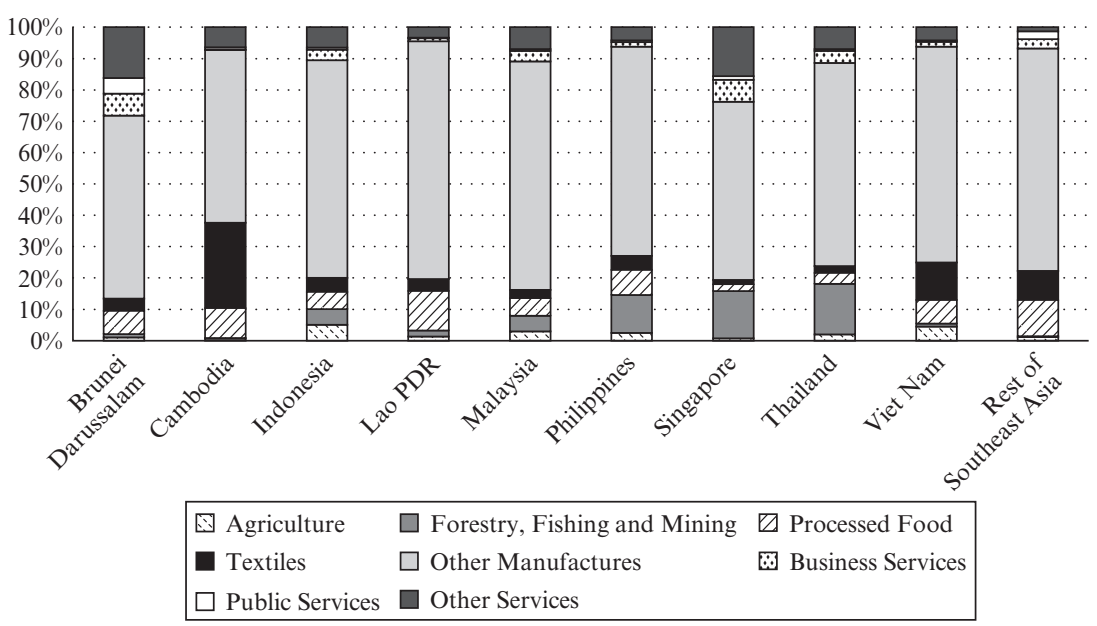

Note: $\quad$ Lao PDR $=$ Lao People's Democratic Republic.

Source: Authors' calculations based on GTAP/GMig2 Data Base version 9.

Figure 3.7 Imports by commodity, 2011 (\% share) 


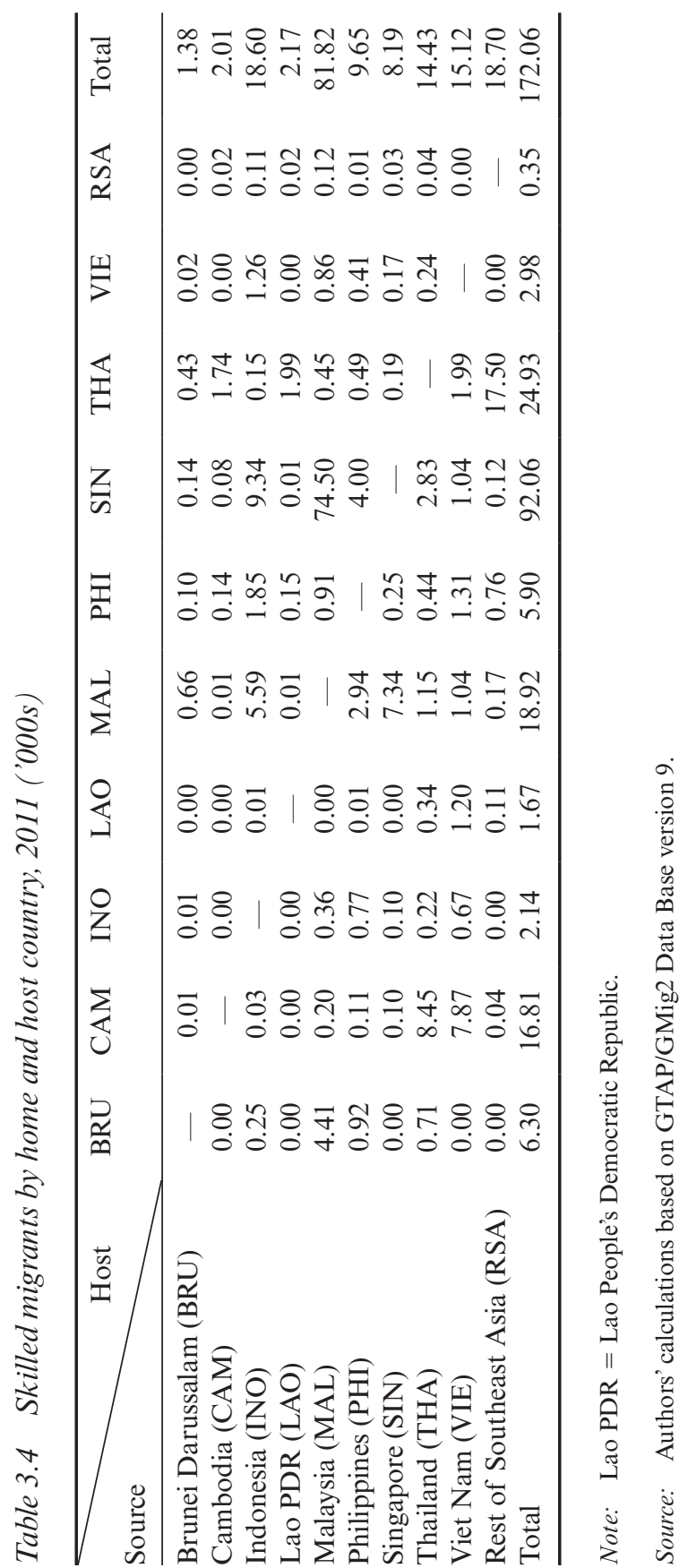




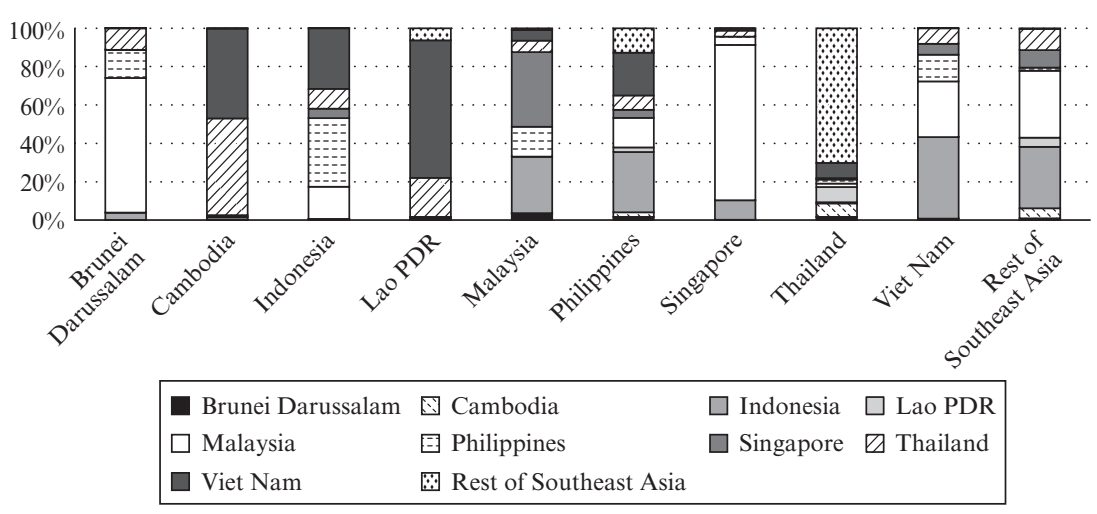

Note: $\quad$ Lao PDR $=$ Lao People's Democratic Republic.

Source: Authors' calculations based on GTAP/GMig2 Data Base version 9.

Figure 3.8 Composition of skilled migrants by host country (\%)

indicates that intra-ASEAN skilled labor migration is mainly concentrated along nine corridors: (i) Malaysia to Brunei Darussalam and Malaysia to Singapore; (ii) Thailand to Cambodia and Viet Nam to Cambodia; (iii) the Philippines to Indonesia and Viet Nam to Indonesia; (iv) Viet Nam and Thailand to the Lao PDR; (v) Singapore and Indonesia to Malaysia; (vi) Indonesia, Malaysia and Viet Nam to the Philippines; (vii) the Rest of Southeast Asia (primarily Myanmar) to Thailand; (viii) Indonesia, Malaysia and the Philippines to Viet Nam; and (ix) Indonesia, Malaysia and Thailand to the Rest of Southeast Asia (both Myanmar and Timor-Leste).

\section{POLICY SCENARIOS AND RESULTS}

We conducted three policy experiments (scenarios) to analyze the potential economic impact of skilled labor mobility due to MRAs:

AFTA: Completely remove intra-ASEAN tariffs to understand the economic impact associated with AFTA alone - where skills mobility within the AEC is not allowed.

AFTA-SKILL: Endogenous labor mobility is added to the AFTA scenario. This simulates the policy of allowing skilled professionals to migrate within the AEC based on real wage differences between their source and host countries. 


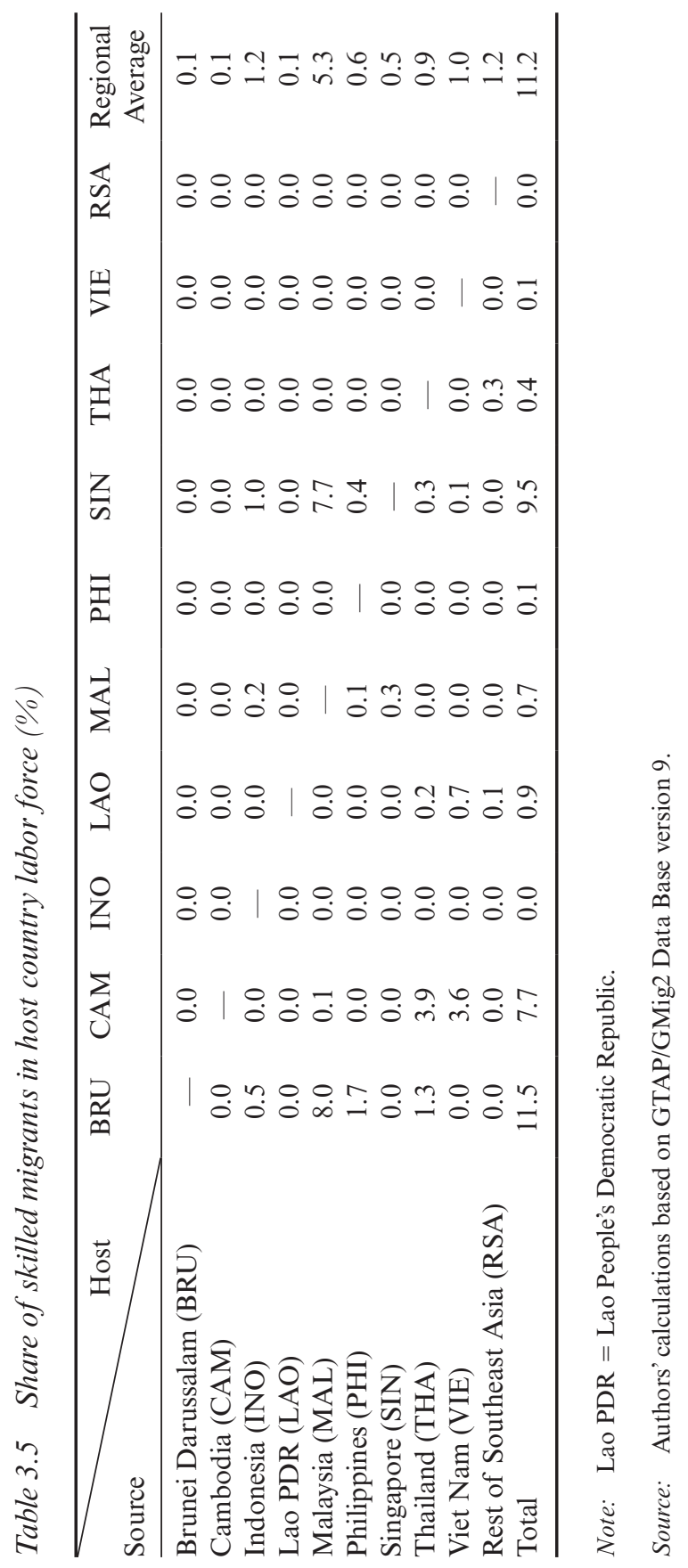


Table 3.6 Effects on gross domestic product (\% change)

\begin{tabular}{lccc}
\hline Country & AFTA & AFTA-SKILL & AFTA-WAGE \\
\hline Brunei Darussalam & 0.19 & 0.20 & 0.81 \\
Cambodia & 0.12 & 0.18 & 0.61 \\
Indonesia & 0.02 & 0.02 & 0.50 \\
Lao People's Democratic & -0.14 & -0.14 & 0.24 \\
$\quad$ Republic & & & \\
Malaysia & 0.16 & 0.13 & 1.10 \\
Philippines & 0.08 & 0.08 & 1.01 \\
Singapore & 0.05 & 0.06 & 1.68 \\
Thailand & 0.06 & 0.06 & 0.76 \\
Viet Nam & 0.15 & 0.15 & 0.85 \\
Rest of Southeast Asia & -0.01 & -0.01 & 0.50 \\
\hline
\end{tabular}

Note: $\quad$ AFTA $=$ ASEAN Free Trade Agreement.

Source: Simulation results.

\begin{abstract}
AFTA-WAGE: This takes the AFTA-SKILL scenario and adds 5\% to the initial ratio of migrant wages relative to those of permanent residents - as calibrated from the initial GMig2 Data Base. This scenario simulates an AEC-wide policy designed to improve migrant salary conditions.
\end{abstract}

The three scenarios clearly build upon each other. The AFTA scenario does not allow for bilateral labor movements, while the last two allow for skilled labor mobility within the AEC. We do this to isolate the economic impact of tariff elimination due to AFTA from those arising from the freer flow of skilled labor within the AEC.

Table 3.6 shows the GDP impact of the three policy scenarios. The first column shows that tariff eliminations due to AFTA generally result in GDP gains for AEC members. Exceptions are the Lao PDR and the Rest of Southeast Asia, which show marginal GDP contractions $(-0.14 \%$ and $-0.01 \%$ respectively) driven by larger imports. Among AEC members, Brunei Darussalam gains the most $(0.19 \%)$, followed by Malaysia $(0.16 \%)$, Viet Nam $(0.15 \%)$ and Cambodia $(0.12 \%)$. Other AEC members show GDP expansions below $0.1 \%$.

GDP gains under AFTA are quite small for two reasons. First, ASEAN tariffs are already low due to successive tariff reductions over the last decade under the Common Effective Preferential Tariff (CEPT) mechanism (see Figure 3.5). Second, total intra-ASEAN trade is quite small 
relative to global trade-AEC members trade more outside the region than within the community (see Table 3.3 for initial bilateral trade flows). The GDP impact on countries outside the AEC is negligible (not shown in Table 3.6), which suggests that eliminating tariffs in the AEC does not appear to cause trade diversion for the same two reasons.

To better understand and analyze the effects of these policy scenarios on skilled migrant movements, we break down the impact of the three scenarios by expenditure-side GDP (Table 3.7), by price index (Table 3.8), by the number of skilled migrants affected (Tables 3.9 and 3.10) and by the impact on trade and current account balances (Table 3.11).

Table 3.7 presents the percentage changes by expenditure-side GDP aggregate on each AEC economy. The AFTA results, shown in the upper panel, suggest that eliminating tariffs increases trade for all members. Exports increase for all countries except Viet Nam and Brunei Darussalam, as their aggregate export price index (which measures the cost of producing exports) increases more than any other AEC member (Table 3.8), resulting in reduced external demand for their exports. A comparison of the export and import percentage changes show imports growing more than exports in all AEC members. This is due to the higher demand for investment goods and imported intermediate inputs needed to support export expansion. The significant percentage growth in exports and imports for Cambodia, the Lao PDR and the Rest of Southeast Asia (see Table 3.8) should be taken with caution, as these countries have relatively small trade value flows in our initial data. ${ }^{5}$

Eliminating tariffs under AFTA also results in higher investment demand in all AEC members, as imported capital goods become less expensive. Investment increases the most in Viet Nam, followed by Thailand, Malaysia, Brunei Darussalam and Singapore, while the Philippines and the Rest of Southeast Asia show low investment growth rates. Again, the higher investment growth for Cambodia and the Lao PDR should be taken with caution due to their low investment flows in our initial data.

We now turn to changes in household consumption alongside changes in government demand and investments. Movements in these three aggregates are driven by our standard GTAP closure rules and regional household specification. In general, household consumption increases in all AEC economies, except for Cambodia, the Lao PDR and the Rest of Southeast Asia. Final consumption (by household and government) falls in Cambodia because, as shown in Table 3.8, the price of investment falls more than the consumer price index (CPI) and the government price index. As a result, Cambodians are encouraged to save and invest while at the same time reducing private consumption. The higher government price index also leads to a fall in government consumption. For the Lao PDR, 
Table 3.7 Real gross domestic product, expenditure side (\% change from base)

\begin{tabular}{|c|c|c|c|c|c|c|}
\hline Country & Consumption & Investment & Government & Exports & Imports & GDP \\
\hline \multicolumn{7}{|c|}{ Scenario: AFTA } \\
\hline Brunei Darussalam & 0.69 & 2.37 & -0.11 & -0.01 & 1.42 & 0.19 \\
\hline Cambodia & -0.57 & 17.44 & -0.22 & 6.33 & 8.18 & 0.12 \\
\hline Indonesia & 0.06 & 0.37 & -0.01 & 1.15 & 1.73 & 0.02 \\
\hline Lao PDR & -0.33 & 3.91 & 0.03 & 5.67 & 6.57 & -0.14 \\
\hline Malaysia & 0.28 & 2.47 & -0.03 & 0.88 & 1.76 & 0.16 \\
\hline Philippines & 0.32 & 0.71 & 0.02 & 1.55 & 2.04 & 0.09 \\
\hline Singapore & 1.20 & 2.88 & 0.21 & 0.76 & 2.29 & 0.05 \\
\hline Thailand & 0.21 & 3.91 & -0.11 & 1.37 & 2.90 & 0.06 \\
\hline Viet Nam & 1.29 & 8.84 & 0.03 & -1.74 & 2.71 & 0.15 \\
\hline $\begin{array}{l}\text { Rest of Southeast } \\
\text { Asia }\end{array}$ & -0.02 & 0.33 & -0.02 & 1.89 & 1.72 & -0.01 \\
\hline \multicolumn{7}{|c|}{ Scenario: AFTA-SKILL } \\
\hline Brunei Darussalam & 0.70 & 2.38 & -0.09 & -0.01 & 1.43 & 0.20 \\
\hline Cambodia & -0.54 & 17.48 & -0.21 & 6.42 & 8.25 & 0.18 \\
\hline Indonesia & 0.06 & 0.37 & -0.01 & 1.15 & 1.73 & 0.02 \\
\hline Lao PDR & -0.33 & 3.91 & 0.03 & 5.68 & 6.57 & -0.14 \\
\hline Malaysia & 0.25 & 2.48 & -0.04 & 0.91 & 1.81 & 0.13 \\
\hline Philippines & 0.33 & 0.62 & 0.02 & 1.64 & 2.09 & 0.08 \\
\hline Singapore & 1.20 & 2.89 & 0.21 & 0.76 & 2.29 & 0.06 \\
\hline Thailand & 0.21 & 3.91 & -0.11 & 1.37 & 2.90 & 0.06 \\
\hline Viet Nam & 1.29 & 8.84 & 0.03 & -1.74 & 2.72 & 0.15 \\
\hline $\begin{array}{l}\text { Rest of Southeast } \\
\text { Asia }\end{array}$ & -0.02 & 0.33 & -0.02 & 1.89 & 1.73 & -0.01 \\
\hline \multicolumn{7}{|c|}{ Scenario: AFTA-WAGE } \\
\hline Brunei Darussalam & 1.23 & 2.94 & 1.26 & 0.15 & 1.83 & 0.80 \\
\hline Cambodia & -0.17 & 17.93 & -0.14 & 7.00 & 8.80 & 0.61 \\
\hline Indonesia & 0.48 & 0.82 & 0.25 & 1.34 & 2.18 & 0.50 \\
\hline Lao PDR & -0.01 & 4.14 & 0.21 & 6.23 & 7.10 & 0.24 \\
\hline Malaysia & 1.22 & 4.02 & 0.45 & 1.51 & 2.70 & 1.10 \\
\hline Philippines & 1.22 & 1.96 & 0.35 & 1.78 & 2.96 & 1.00 \\
\hline Singapore & 2.83 & 4.98 & 0.83 & 1.94 & 3.58 & 1.66 \\
\hline Thailand & 0.81 & 4.65 & 0.29 & 1.84 & 3.48 & 0.76 \\
\hline Viet Nam & 1.97 & 10.21 & 0.16 & -1.37 & 3.42 & 0.85 \\
\hline $\begin{array}{l}\text { Rest of Southeast } \\
\text { Asia }\end{array}$ & 0.32 & 0.42 & 0.37 & 2.44 & 2.07 & 0.50 \\
\hline
\end{tabular}

Note: $\quad$ AFTA $=$ ASEAN Free Trade Agreement; Lao PDR $=$ Lao People's Democratic Republic.

Source: Simulation results. 
Table 3.8 Gross domestic product price indexes, expenditure side (\% change from base)

\begin{tabular}{|c|c|c|c|c|c|c|}
\hline Country & Consumption & Investment & Government & Exports & Imports & $\begin{array}{l}\text { GDP } \\
\text { price } \\
\text { index }\end{array}$ \\
\hline \multicolumn{7}{|c|}{ Scenario: AFTA } \\
\hline Brunei Darussalam & -1.09 & -0.79 & -0.02 & 0.04 & 0.12 & -0.49 \\
\hline Cambodia & -1.94 & -3.36 & 0.87 & -0.36 & 0.21 & -2.69 \\
\hline Indonesia & 0.26 & 0.25 & 0.42 & 0.23 & 0.12 & 0.30 \\
\hline Lao PDR & -0.05 & -0.16 & -0.77 & -0.07 & 0.11 & -0.24 \\
\hline Malaysia & 0.01 & 0.08 & 0.63 & 0.20 & 0.14 & 0.17 \\
\hline Philippines & 0.51 & 0.46 & 0.78 & 0.51 & 0.07 & 0.70 \\
\hline Singapore & 1.07 & 0.89 & 1.54 & 1.02 & 0.02 & 2.00 \\
\hline Thailand & 0.36 & -0.11 & 1.15 & 0.21 & 0.06 & 0.44 \\
\hline Viet Nam & 1.09 & 1.07 & 2.31 & 1.14 & 0.02 & 2.15 \\
\hline $\begin{array}{l}\text { Rest of Southeast } \\
\text { Asia }\end{array}$ & -0.28 & -0.20 & -0.17 & -0.09 & 0.04 & -0.28 \\
\hline \multicolumn{7}{|c|}{ Scenario: AFTA-SKILL } \\
\hline Brunei Darussalam & -1.10 & -0.80 & -0.06 & 0.04 & 0.12 & -0.50 \\
\hline Cambodia & -1.94 & -3.38 & 0.78 & -0.37 & 0.21 & -2.71 \\
\hline Indonesia & 0.26 & 0.25 & 0.42 & 0.23 & 0.12 & 0.30 \\
\hline Lao PDR & -0.05 & -0.16 & -0.77 & -0.07 & 0.11 & -0.24 \\
\hline Malaysia & 0.00 & 0.08 & 0.63 & 0.19 & 0.14 & 0.16 \\
\hline Philippines & 0.56 & 0.48 & 0.80 & 0.54 & 0.07 & 0.76 \\
\hline Singapore & 1.07 & 0.89 & 1.54 & 1.02 & 0.02 & 2.00 \\
\hline Thailand & 0.36 & -0.11 & 1.15 & 0.21 & 0.06 & 0.44 \\
\hline Viet Nam & 1.09 & 1.07 & 2.31 & 1.14 & 0.02 & 2.15 \\
\hline $\begin{array}{l}\text { Rest of Southeast } \\
\text { Asia }\end{array}$ & -0.28 & -0.20 & -0.17 & -0.09 & 0.03 & -0.28 \\
\hline \multicolumn{7}{|c|}{ Scenario: AFTA-WAGE } \\
\hline Brunei Darussalam & -1.44 & -1.09 & -1.36 & 0.05 & 0.10 & -0.98 \\
\hline Cambodia & -1.92 & -3.45 & 0.12 & -0.45 & 0.19 & -2.79 \\
\hline Indonesia & 0.17 & 0.14 & -0.89 & 0.24 & 0.11 & 0.09 \\
\hline Lao PDR & -0.02 & -0.15 & -1.72 & -0.10 & 0.09 & -0.32 \\
\hline Malaysia & -0.16 & -0.04 & -0.30 & 0.11 & 0.13 & -0.13 \\
\hline Philippines & 0.50 & 0.49 & -0.84 & 0.54 & 0.07 & 0.54 \\
\hline Singapore & 0.73 & 0.64 & 0.50 & 0.79 & 0.03 & 1.42 \\
\hline Thailand & 0.29 & -0.17 & 0.01 & 0.16 & 0.07 & 0.19 \\
\hline Viet Nam & 1.03 & 0.97 & 1.39 & 1.10 & 0.02 & 1.98 \\
\hline $\begin{array}{l}\text { Rest of Southeast } \\
\text { Asia }\end{array}$ & -0.37 & -0.32 & -1.89 & -0.10 & 0.03 & -0.60 \\
\hline
\end{tabular}

Note: $\quad$ AFTA $=$ ASEAN Free Trade Agreement; Lao PDR $=$ Lao People's Democratic Republic.

Source: Simulation results. 


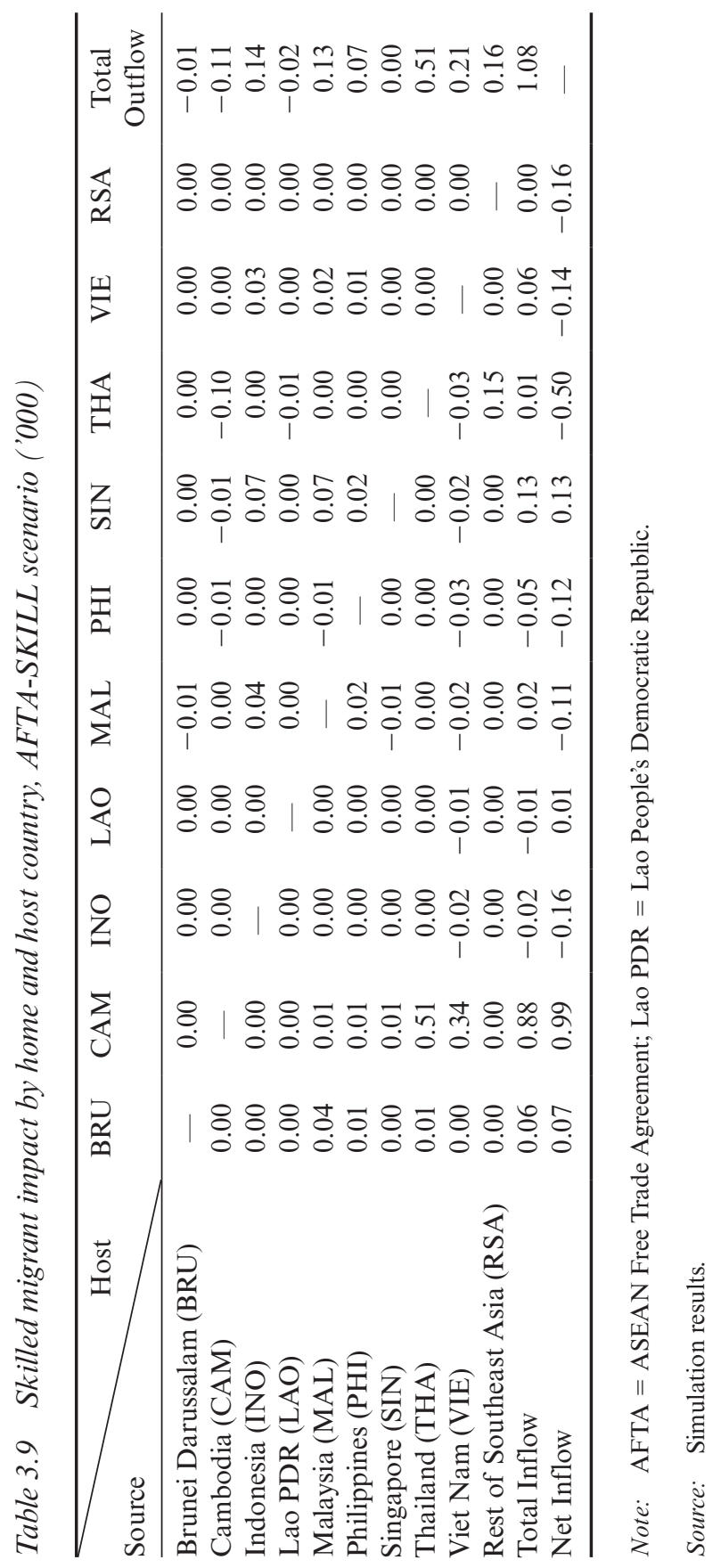




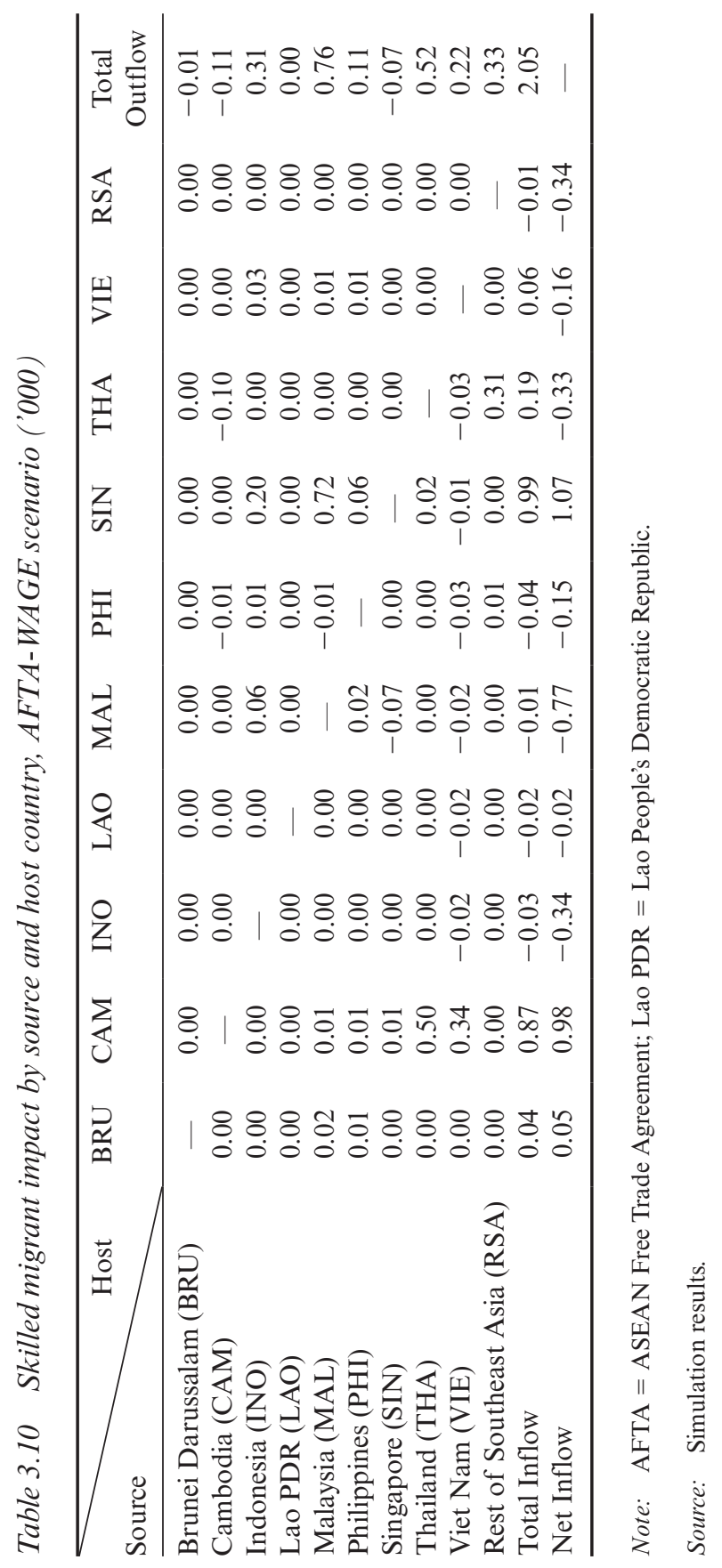




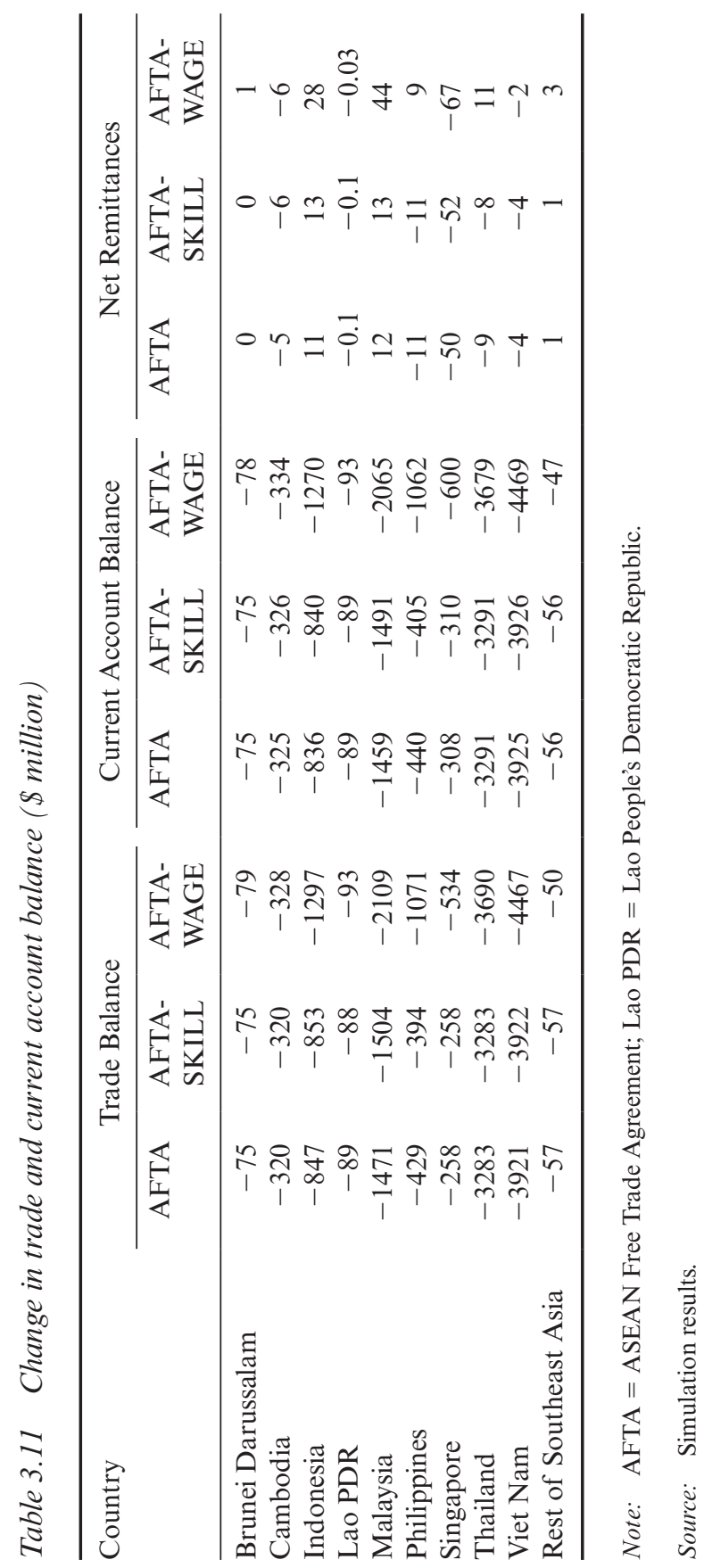


consumption decreases because the reduction in the investment price index outweighs the reduction in the CPI-thereby encouraging investmentswhile government consumption rises due to the falling government price index. A higher government price index also results in reduced government consumption in Indonesia and Thailand.

The second column of Table 3.6 shows the GDP impact of our AFTASKILL simulation - which combines AFTA with skilled labor mobility within the AEC. Here we allow migrants to respond to real wage differences between source and host country. The results show that GDP changes are similar to those of the AFTA scenario because of limited skilled migration within the region ( 1,080 people; see Table 3.9). There are two reasons for this. First, we assume skilled migrants have a unitary elasticity $\left(\sigma_{i, c, r}=1\right)$, thereby tempering their response to relative wage differences between source and host country. Second, the small increase in skilled labor migration is linked to our benchmark data, which shows limited intra-ASEAN skilled migration at the base (see Table 3.4).

Nevertheless, we see that GDP expands a bit more for Cambodia $(0.12 \%$ AFTA vs. $0.18 \%$ AFTA-SKILL) as migrants reduce the shortage of skilled labor, hence increasing the overall labor force. Brunei Darussalam and Singapore also increase GDP as a result of employing more skilled migrants from other ASEAN countries. As shown in the last row of Table 3.9, the higher GDP for these three AEC members is anchored on higher skilled labor intake. In terms of source country, skilled migrants to Cambodia come from Thailand and Viet Nam, while Singapore absorbs skilled workers from Malaysia and the Philippines. Malaysia, on the other hand, registers a GDP contraction because of a reduction in labor forcea net skilled migrant outflow of 1,100 (see Table 3.9).

The middle panel of Table 3.7 shows the percentage changes in each GDP aggregate from the expenditure side under the AFTA-SKILL scenario. In general, the magnitudes are similar to those under the AFTA scenario. An exception is Malaysia, which shows marginally lower household consumption changes and marginally higher export and import changes under AFTA-SKILL than under the AFTA scenario. These differences are driven by changes in Malaysia's current account balance $(\mathrm{CAB})$. The net migrant outflow in Malaysia (higher outflows of skilled Malaysian workers than inflows from other AEC economies) leads to higher remittance inflows, which improve Malaysia's CAB (Table 3.11). This improvement means Malaysia's real exchange rate will depreciate less under AFTA-SKILL than under the AFTA scenario. This results in less expensive imports and thus feeds import demand. Exports expand slightly as Malaysia's export price index increases less under AFTA-SKILL $(0.19 \%$ vs. $0.20 \%$ in the AFTA scenario; see Table 3.8) due to the lower cost of 
imported intermediate inputs. Similarly, investments increase as imported capital goods become relatively less expensive.

The third column of Table 3.6 shows the impact on GDP of our third simulation-AFTA-WAGE - which combines AFTA-SKILL with a 5\% improvement in the initial ratio of migrant wages relative to permanent residents in the host country. Here, we find the impact on GDP is both positive and much higher than in the first two scenarios. Among AEC members, Singapore gains most (a 1.6\% GDP expansion), followed by Malaysia (1.10\%) and the Philippines (1.01\%). All other AEC members show GDP gains ranging between $0.5 \%$ and $0.8 \%$. The Lao PDR and the Rest of Southeast Asia likewise register GDP gains, as opposed to contractions in our first two scenarios.

The GDP expansions for Brunei Darussalam, Cambodia and Singapore are again anchored on skilled labor intake (see Table 3.10). Although Indonesia, the Lao PDR, Malaysia, the Philippines, Thailand, Viet Nam and the Rest of Southeast Asia show net migrant outflows (see Table 3.10), their GDP still increases as a result of higher export sales and greater household consumption (see Table 3.7) - associated with higher remittances. Indeed, the lower panel of Table 3.7 shows that the percentage changes in each GDP aggregate from the expenditure side are all higher under AFTA-WAGE than AFTA-SKILL scenarios. Close examination of Table 3.7 reveals that consumption, exports and imports increase more under AFTA-WAGE when compared with the first two scenarios; real investment increases only slightly under AFTA-WAGE. Essentially, all these changes are influenced by changes in the current account balance. Except in Singapore, the net migrant intake under AFTA-WAGE is lower when compared with the AFTA-SKILL scenario. This is because the 5\% improvement in the initial ratio of migrant wages relative to permanent host country residents' results in reduced demand for skilled migrants as they become more expensive.

Table 3.11 shows that the $\mathrm{CAB}$ deteriorates more than the trade balance in Cambodia, the Lao PDR, Singapore and Viet Nam. This creates real exchange rate depreciation, making exports less expensive (see Table 3.8). On the other hand, higher net remittances slightly improved the CAB relative to trade balances in Brunei Darussalam, Indonesia, Malaysia, the Philippines, Thailand, and the Rest of Southeast Asia. This reduces the real exchange rate depreciation under AFTA-WAGE when compared with the AFTA-SKILL scenario. Exports still grow significantly in these countries as their slightly lower real exchange rate depreciation means less expensive imported inputs (again compared with AFTA-SKILL), which translates into lower export price indices under the AFTA-WAGE scenario (see Table 3.8). 


\section{INSIGHTS AND FURTHER WORK}

In this chapter, we analyze the potential economic impact of the freer flow of skilled labor within the AEC with the aid of the GMig2 Data Base and model. We also fill a research gap by shedding light on how skilled labor mobility within the AEC might impact each ASEAN economy.

Our analysis of benchmark GMig2 data indicates that skilled migrants account for just $12 \%$ of the roughly 1.5 million intra-ASEAN migrantsand that intra-ASEAN migrants account for only a small share of ASEAN's total skilled labor force. We also find from our initial data that intra-ASEAN skilled labor migration is mainly linked to geographical proximity and cultural similarity, thus limiting bilateral labor movements to a few countries.

Our simulation results suggest that economic gains from tariff elimination under AFTA are relatively small because past tariff reductions under CEPT already reduced tariffs to low levels, and because intra-ASEAN trade remains small relative to AEC members' external trade. Nonetheless, we find that a policy allowing freer flow of skilled labor and one with a $5 \%$ increase in the initial ratio of migrant to permanent resident wages in the host country would increase GDP across AEC economies. GDP gains from the income side come from the greater supply of skilled labor, while GDP gains from the expenditure side come from higher investments and exports - as imported intermediate inputs become less expensive and higher consumption results from higher remittances sent home by migrant workers.

This is just an initial attempt to analyze the potential impact of skilled labor mobility under AEC MRAs on professional services. So far, MRAs facilitate the freer flow of eight professions - accountants, architects, dentists, engineers, medical practitioners, nurses, land surveyors and tourism professionals. An important caveat of the analysis is that the GDP gains under our two skilled mobility scenarios are likely overestimated. This is because the GMig2 data we use distinguishes only unskilled and skilled workers, with the latter representing all skilled labor types, not just those covered by existing MRAs. Therefore, further work is needed to disaggregate the eight MRA occupations from the current homogeneous skilled labor category in the GMig2 Data Base and model. Doing this would pave the way for a better understanding of the potential economic impact of freer flows of skilled labor within the AEC.

In summary, we find that the gains from freer flows of skilled labor within the AEC are maximized when complementary policies aimed at reducing national-level barriers-reducing wage differentials between migrants and permanent residents, among others - are also implemented. 
Further dialogue is needed, followed by a concerted effort among AEC members to pursue accommodative domestic policies. This would maximize not only migrant welfare, but also the economic gains each AEC member stands to reap from the freer flow of skilled labor across the AEC.

\section{NOTES}

1. Under the Common Effective Preferential Tariff (CEPT) scheme, tariff elimination excludes products classified under: Temporary Exclusions, Sensitive Products and General Exclusions.

2. The "source" country/region is defined as a worker's place of origin/birth, while the "host" country/region is where that same worker currently resides/works.

3. The GMig2 Data Base only distinguishes unskilled and skilled labor types, with the latter category also including skilled labor beyond the eight professional occupations covered by MRAs.

4. We proceed under the assumption that "Rest of Southeast Asia" is part of the AEC, even with Timor-Leste included (although it remains outside ASEAN).

5. A small initial value (such as Cambodia's exports) would result in a higher percentage change growth relative to a high initial value (such as Singapore's exports). For example, if the initial exports of commodity $c$ by countries A and country B are $\$ 1$ and $\$ 10$ respectively, and assuming their exports increase by $30 \%$ and $5 \%$, then the post-simulation value of exports would be $\$ 1.30$ and $\$ 10.50$ for countries A and B respectively. Note that international trade in GMig2 follows the Armington assumption. This implies that changes in trade flows are preconditioned on initial trade shares; a country with a small initial exports share could not instantly gain a bigger market share.

\section{REFERENCES}

Aguiar, A., B. Narayanan, and R. McDougall (2016), An Overview of the GTAP 9 Data Base. Journal of Global Economic Analysis, 1(1): 181-208.

Asian Development Bank (2015), ASEAN 2030: Toward a Borderless Economic Community. Manila: ADB.

Brockmeier, M. (2001), A Graphical Exposition of the GTAP Model. GTAP Technical Paper No. 8. Center for Global Trade Analysis. Purdue University.

Corong, E., T. Hertel, R. McDougall, M. Tsigas, and D. van der Mensbrugghe (2017), The Standard GTAP Model, Version 7. Journal of Global Economic Analysis, 2(1): 1-119. http://dx.doi.org/10.21642/JGEA.020101AF.

Docquier, F., A. Marfouk, C. Ozden, and C.R. Parsons (2010), Geographic, Gender and Skill Structure of International Migration. Report written for the Economic Research Forum.

Hertel. T. W. (1997), Global Trade Analysis: Modeling and Applications. Cambridge: Cambridge University Press.

Ozden, C., C.R. Parsons, M. Schiff, and T. Walmsley (2010), The Evolution of Global Bilateral Migration 1960-2000. Paper presented at the Second Migration and Development Conference. September 2009: Washington, DC.

Sugiyarto, G. and D.R. Agunias (2014), A 'Freer' Flow of Skilled Labour within 
ASEAN: Aspirations, Opportunities and Challenges in 2015 and Beyond. Bangkok and Washington, DC: International Organization for Migration and Migration Policy Institute.

Walmsley, T., A. Winters, S.A. Ahmed, and C. Parsons (2007), Measuring the Impact of the Movement of Labour Using a Model of Bilateral Migration Flows. GTAP Technical Paper No. 28. Center for Global Trade Analysis. Purdue University. 


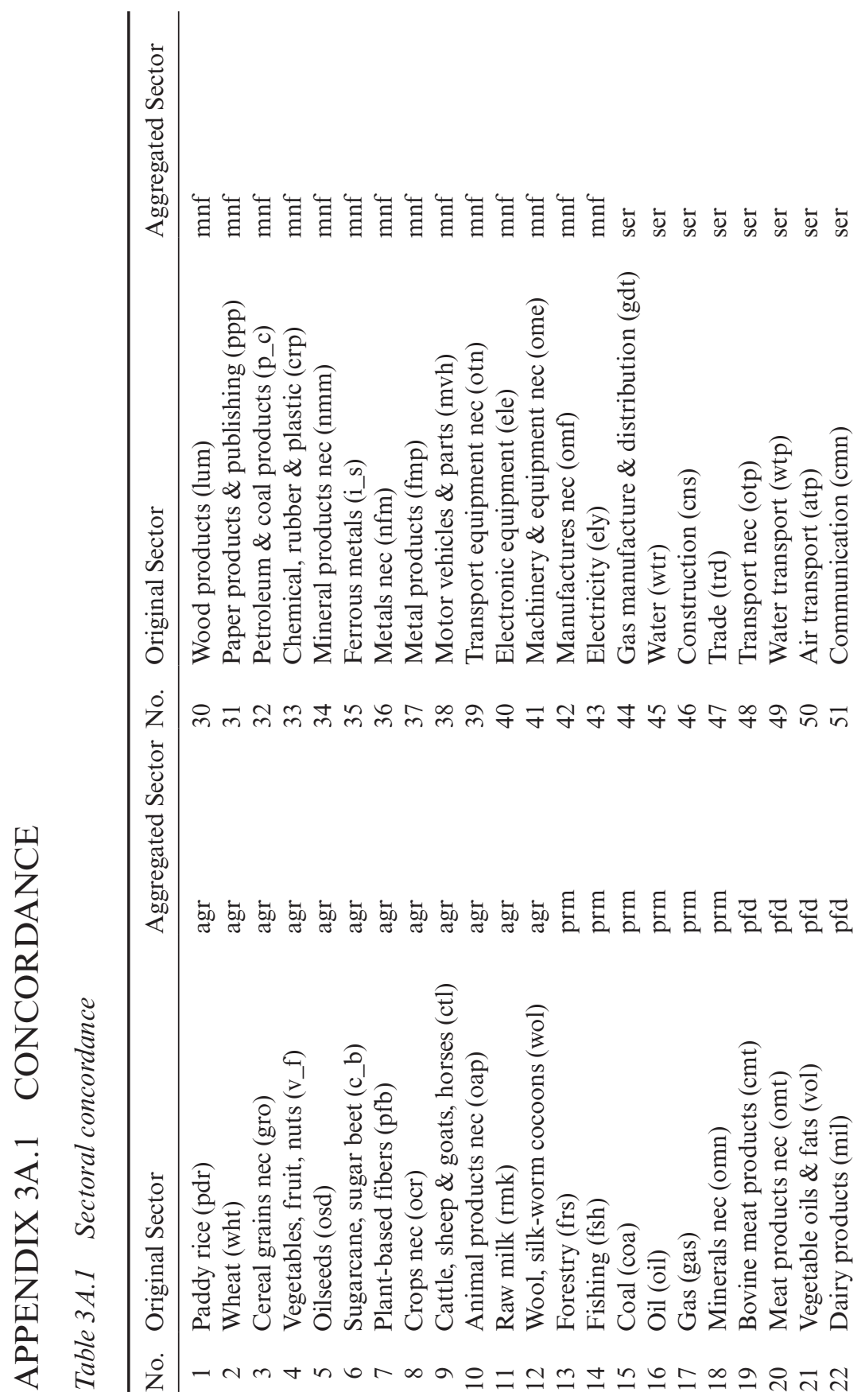




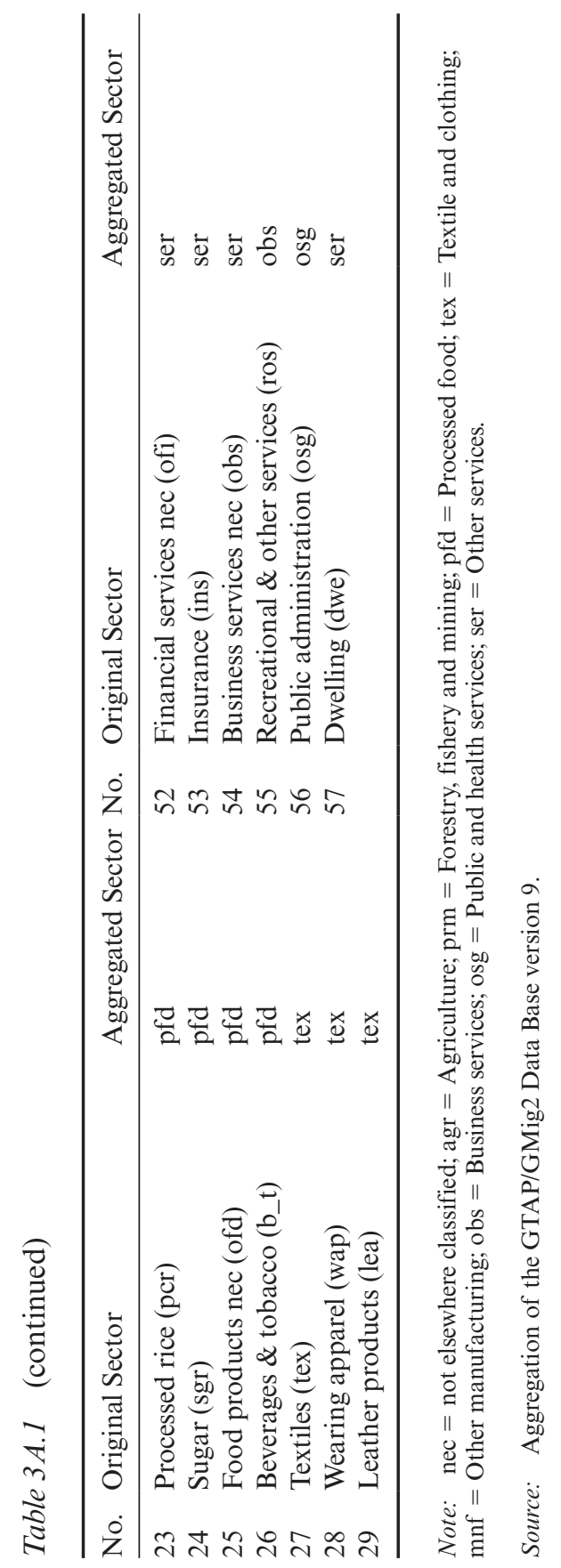




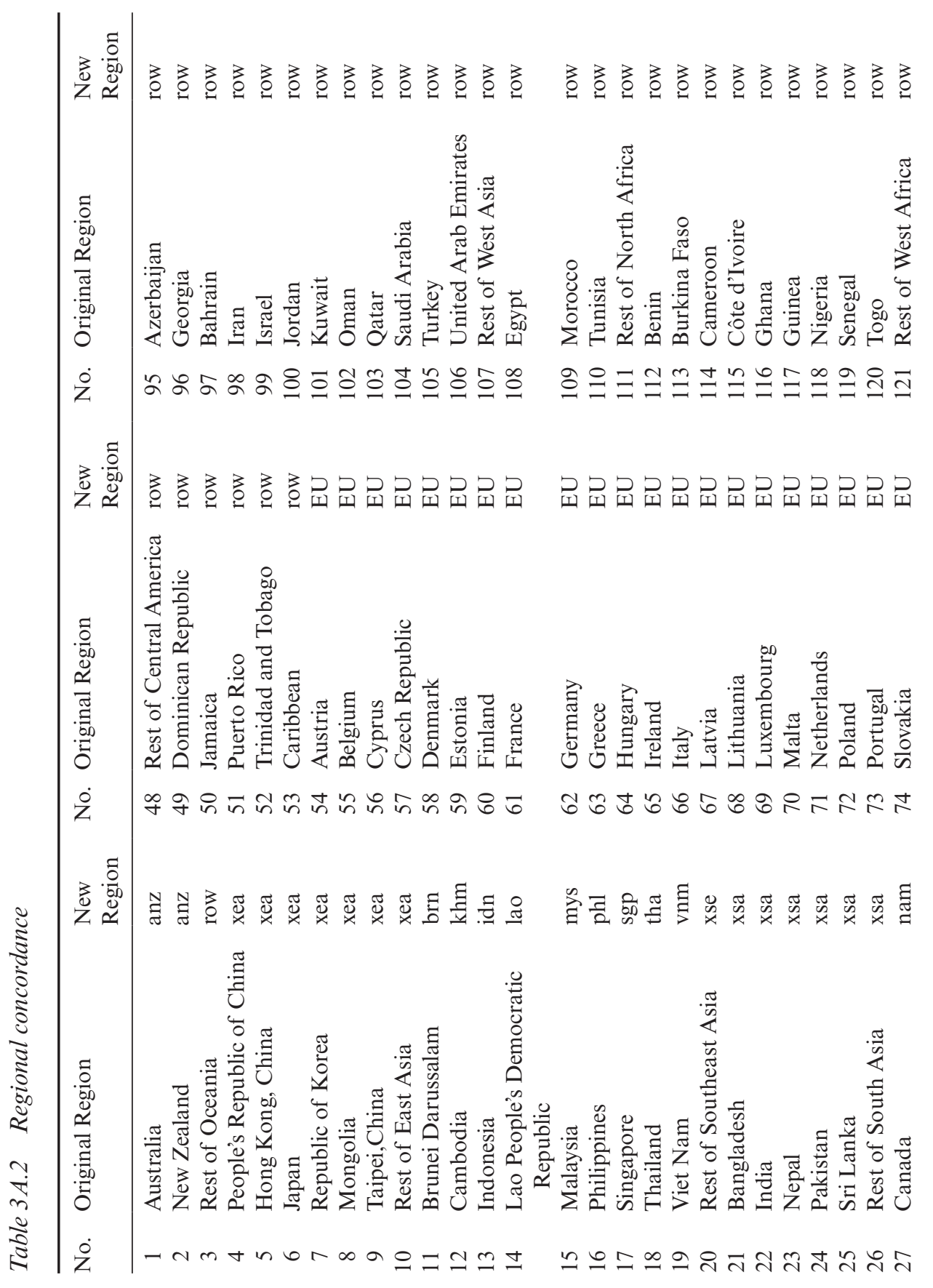




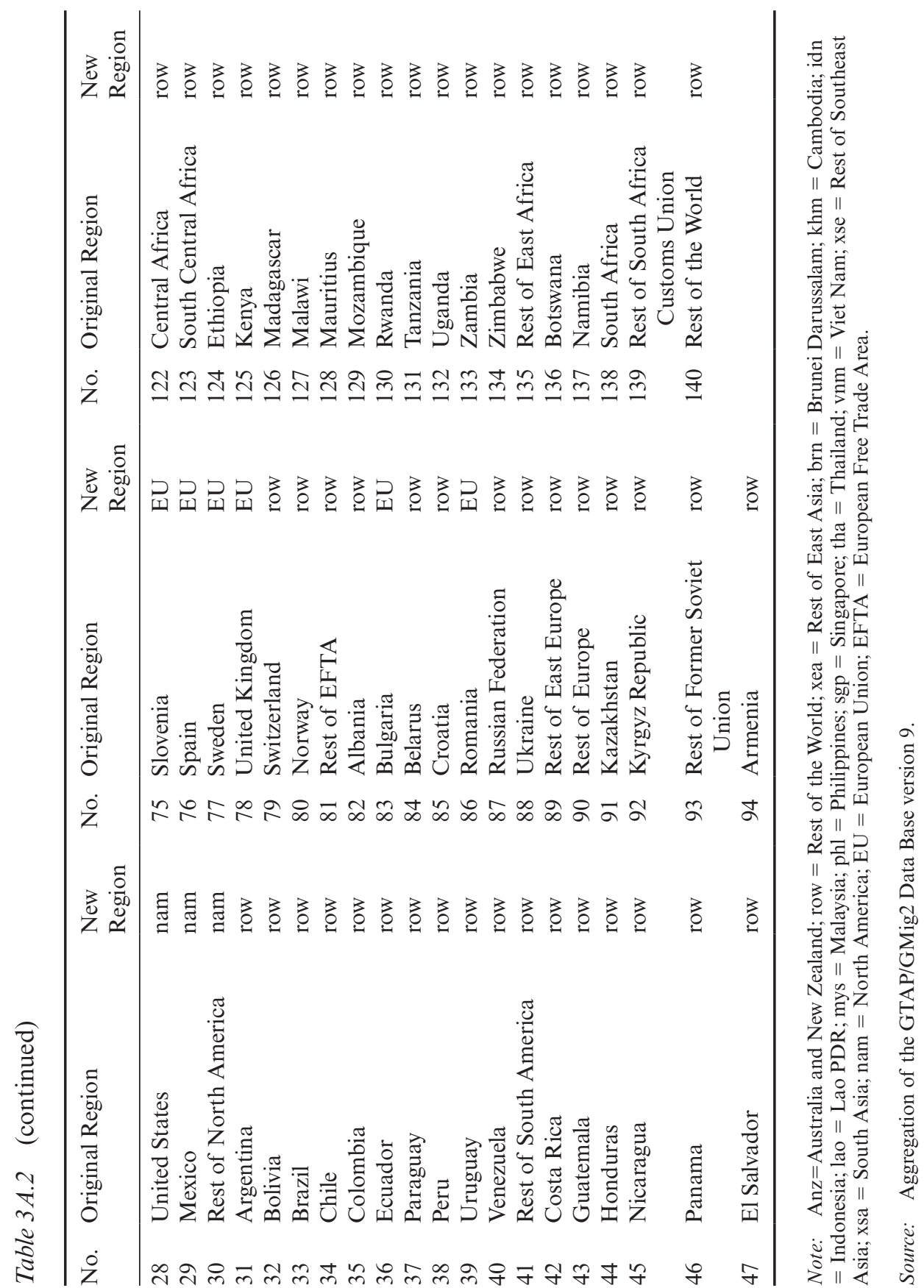

